\title{
Lung Large Cell Carcinoma with Rhabdoid Phenotype
}

National Cancer Institute

\section{Source}

National Cancer Institute. Lung Large Cell Carcinoma with Rhabdoid Phenotype. NCI

Thesaurus. Code C6876.

A large cell lung carcinoma characterized by the presence of rhabdoid cells. 